УДК 352:323.382:008.8(043.3)

\title{
ПіАвищення ефективності проектів партнерства на рівні міста
}

\author{
С.А. ЗАПОРОЖЕЦЬ \\ ОАеський регіональний інститут Аержавного управління \\ Національної акалемії Аержавного управління при Презилентові України, \\ м. Oseca, Україна, E-mail: sergzap@yandex.ru
}

\begin{abstract}
Авторське резюме
На основі аналізу наукових джерел визначено необхідність використання механізмів партнерства в управлінні містом, проаналізовано проблеми запровадження механізмів партнерства на рівні міста.

Визначено основні фактори, що впливають на ефективність використання механізмів партнерства на рівні міста, а саме: відсутність ефективних можливостей для повноцінного та системного контролю з боку громади за діяльністю місцевої ради, брак інформації щодо змісту рішень, які ухвалюються міськими радами, складність процесу контролю за імплементацією політики в місті, недосконала звітність про діяльність органів місцевого самоврядування, непрозорі бюджетні процеси, відсутність скоординованої та скоригованої політики партнерства, недосконалість законодавчої бази партнерських відносин; нечітке визначення ролі та статусу учасників партнерства; недоццінка органами місцевого самоврядування на рівні міста людського капіталу; відсутність належної пропаганди позитивних прикладів партнерської взаємодії; відсутність налагоджених зв'язків, що сприяли б обміну досвідом реалізації соціальних та бізнес-проектів; відсутність матеріальної бази. Це зумовлює необхідність наукового дослідження сутності та змісту партнерства як форми балансу інтересів органів місцевого самоврядування і громадського та бізнес-середовища, сучасних механізмів їх взаємодії, як інструменту інвестиційно-інноваційного забезпечення розвитку міст. Важливою метою будь-якої з форм партнерства є залучення інвестицій для вирішення певних суспільно-економічних завдань, важливих для надання суспільних послуг та підвищення якості життя в місті

Ключові слова: місцеве самоврядування, управління містом, партнерство, публічно-приватне партнерство, система управління партнерством, адаптивна модель управління, проблеми в управління партнерством, громада.
\end{abstract}

\section{An increase of efficiency of projects of partnership is at the level of city}

\section{S.A. ZAPOROZHEC \\ Odessa regional institute of public administration of the National academy of public administration, office of the President of Ukraine, Odessa, Ukraine, E-mail: sergzap@yandex.ru}

\section{Abstract}

On the basis of analysis of scientific sources certainly necessity of the use of mechanisms of partnership for a management a city, the problems of introduction of mechanisms of partnership are analysed at the level of city.

Certainly basic factors which influence on efficiency of the use of mechanisms of partnership at the level of city, namely: absence of effective possibilities for valuable and system control from the side of society after activity of local advice, shortage of information on maintenance of decisions which are accepted city advices, complication of control process after implementation of policy in town, imperfect accounting about activity of organs of local government, opaque budgetary processes, absence of the co-ordinated and

(ㄷ) С.А. Запорожець, 2015 
corrected policy of partnership, imperfection of legislative base of partner relations; unclear determination of role and status of participants of partnership; underestimation by the organs of local government at the level of city of human capital; absence of the proper propaganda of positive examples of partner co-operation; absence of the adjusted connections which would be instrumental in the exchange of realization of social and business projects experience; absence of financial base. It predetermines the necessity of scientific research of essence and maintenance of partnership as forms of balance of interests of organs of local government and public and business space, modern mechanisms of their cooperation, as to the instrument of the investment-innovative providing of development of cities. By an important purpose any of forms of partnership there is bringing in of investments for the decision of set social-economic tasks, important for a grant public services and upgrading life, in town

Keywords: local government, management, partnership, in public private partnership, control the system by partnership, adaptive case, problem frame, a city, by ууправління partnership, society.

Постановка проблеми. В сучасних умовах розвитку країни розвиток ефективних партнерських відносин між органами місцевого самоврядування, бізнесом та некомерційними організаціями знаходиться на невисокому рівні, зокрема, поки що не сформовано ефективного інституціонального середовища та цілісної системи інститутів партнерства. Відносна диференційованість існуючих підсистем функціонування міста, таких як політична, економічна, соціальна виявляється розмитою та наповненою сукупністю протиріч. Виникає необхідність знайти засоби їх узгодження та гармонізації, встановлення консенсусу, вироблення взаємоприйнятних рішень, тобто формування ефективного партнерства між різними підсистемами функціонування міста

Мета дослідження. Узагальнення теоретичних підходів до управління містом на основі партнерства та визначення шляхів використання інструментів партнерства на рівні міста в практиці державного управління в Україні.

Аналіз досліджень і публікацій. Розробці різних аспектів управління містом на засадах партнерства сприяли наукові праці таких учених, як Д. Амунц, О. Бобровська, Ю.Вдовенко, С.Грищенко, Б.Данилишин, С.Данасарова, Б.Дезілець, Н. Дутко, І. Запатріна, П. Захарченко, Є.Ж данко, А.Крупник, Ю.Куц, Мамонова, Ю. Молодожен, В.Михеєв, Н.Мущинська, П.Надолішній, Т. Пахомова, Н. Піроженко, О. Полякова, В.Ребок, С. Саханенко, С. Серьогін, В. Толкованов, О. Чебан, Ю. Шаров, Ю.Шевчук тощо.

Але, незважаючи на значний внесок вітчизняних та зарубіжних науковців у формування емпіричної і теоретичної бази знань з вивчення питань використання технологій партнерства в органах державного управління та органах місцевого самоврядування, комплексного дослідження потребують підходи до формування системи на рівні міста, що й зумовило вибір теми публікації.

Виклад основного матеріалу. Розглянуто основні дослідницькі підходи до визначення сутності партнерства в управлінні містом. Визначено, що рівень вивчення проблеми партнерської взаємодії пов'язаний із аналізом структурних елементів даного соціального феномена, в якому партнерство досліджується як характеристика (властивість, атрибут) соціальної взаємодії. Такі дослідження здійснюються в межах соціально-філософських і соціологічних теорій та концепцій. Основні характеристики соціальної взаємодії як категорії загального рівня розроблені у працях П. Бурдьє, М. Вебера, Е. Гідденса, Н. Смелзера, П. Сорокіна, Т. Парсонса та ін. Дослідженням проблем співвідношення влади, держави і права, громадянських і політичних свобод, розподілу влади як показника рівня становлення громадянського суспільства присвячені роботи П. Новгородцева, О. Панаріна, В. Алексєєва та ін.

Визначено, що в наукових джерелах та сучасній практиці можна зустріти наступні терміни, які використовуються для характеристики партнерства: приватно - державне партнерство; партнерство держави і приватного сектора; муніципально - приватне партнерство;приватно - суспільне партнерство; приватно - державна кооперація; пуб- 
лічно-приватне партнерство; суспільноприватне партнерство тощо.

Усі вони по своєму відображають різні аспекти даного явища і вельми корисні для наукового осмислення. Узагальнення теоретичного і практичного міжнародного досвіду підтверджує тезу про те, що з публічно-приватним партнерством пов'язана принципово нова якість реалізації функцій держави в умовах демократичних реформ.

Узагальнення теоретичного і практичного міжнародного досвіду підтверджує тезу про те, що з використанням механіз мів партнерства пов'язана принципово нова якість реалізації функцій місцевого самоврядування в умовах демократичних реформ.

Визначено, що партнерство між органами місцевого самоврядування бізнесом та недержавними організаціями сприяє певному переосмисленню змісту функцій органів місцевого самоврядування.

Важливим є також і те, що із зростанням рівня життя, освітнього і культурного рівня суспільства змінюється характер реалізації традиційних продуктів та послуг органів місцевого самоврядування. Певний перелік класичних публічних благ - освіта, охорона здоров'я, житлово-комунальні послуги, культура - населення вважає за краще повністю або частково оплачувати самостійно, тобто розглядає їх як приватні блага. У цьому зв'язку основні функції місцевого самоврядування переміщуються 3 проблеми забезпечення суспільними благами як такими у бік гарантування їх достатності та належної якості.

Обгрунтовано, що організація регулюючої діяльності органів місцевого самоврядування на рівні міста у сфері партнерства з приватним бізнесом та недержавними організаціями може відбуватися в наступних напрямах.

По-перше, розробляються стратегія і принципи, на яких формуються відносини бізнесу з суспільством в цілому і з органами місцевого самоврядування зокрема.

По-друге, формується інституційне забезпечення для розробки і реалізації партнерських проектів.

По-третє, здійснюються організація та управління партнерством, розробляються його форми і методи, а також конкретні механізми.

Констатовано, що досягнення певного рівня розвитку кожним із учасників парт- нерської взаємодії, поступове зміцнення цілісності соціуму міста через встановлення і розвиток різноманітних відносин між ними вимагає якісно нового підходу до їх взаємодії. Ця взаємодія повинна грунтуватися 3 урахуванням інтересів кожного, ефективного використання їх ресурсів i можливостей, що може привести до вирішення соціальних проблем соціуму за мінімальних витрат. Партнерство, що передбачає налагодження організованої взаємодії людей, їхніх співтовариств, соціальних груп є невід’ємною складовою соціального механізму демократичного врядування. Саме через механізми, процедури, інституції соціального партнерства як окремих громадян, так і певних їх груп доводять до влади свої інтереси, здійснюють свої юридичні права, виконують свої зобов'язання i врегульовують суперечності. Відтак забезпечується налагодження організованої взаємодії людей, їх співтовариств, соціальних груп, розуміння пріоритету загальних інтересів і цілей над меркантильними i необхідності дотримання взаємних зобов'язань і відповідальності, що сприяє стабільності в суспільстві.

Визначено, що сутність партнерства в управлінні містом полягає в налагодженні конструктивної взаємодії між учасниками, діючими на рівні міста (органами місцевого самоврядування, комерційними підприємствами і громадським сектором). Така модель взаємовідносин забезпечує необхідну, особливо на початковій стадії формування демократичної системи урядування, гармонію між громадянським суспільством та органами місцевого самоврядування, створить передумови для прискорення темпів соціально-економічного розвитку України. Детальне дослідження цього процесу - шлях до розуміння того, як улаштовані і як працюють механізми становлення та розвитку партнерства.

Аналізуючи правове поле функціонування партнерства, треба відзначити Закон «Про місцеве самоврядування», який практично дає можливості для його застосування в партнерстві. Так, стаття 26 цього Закону визначає виключні повноваження місцевої ради в п. 22, а саме: «затвердження програм соціально-економічного та культурного розвитку відповідних адміністративно-територіальних одиниць, цільових програм з інших питань місцевого самоврядування»; а в п. 23: «затвердження 
місцевого бюджету, внесення змін до нього; затвердження звіту про виконання відповідного бюджету». Як видно із наедених норм Закону, місцева рада має повне право місцевим нормативним актом затверджувати місцеві програми, у тому числі цільові, а також встановлювати порядок реалізації цих програм. У таких програмах може мати місце партнерство (державно-приватне, соціальне, соціально-самоврядне тощо). Привертає до себе увагу ст.32, п.8 Закону, де йдеться про сприяння діяльності творчих спілок, національно-культурних товариств, асоціацій, інших громадських та неприбуткових організацій, які діють у сфері охорони здоров'я, культури, фізкультури і спорту, роботи з молоддю [1].

Визначено, що, згідно з цією статтею, iï дія може поширюватися як на надання організаціям третього сектора пільг (наприклад, 3 орендної плати за об'єкти комунальної нерухомості), так i до прямого фінансування окремих організацій чи програм, якщо це передбачено місцевим бюджетом. Звичайно, найкраща формула такого сприяння, що перевірена часом за кордоном, а в Україні тільки починає розвиватись - це підтримка програм організацій, які збігаються з пріоритетами, визначеними місцевою владою для власного населеного пункту. Причому така підтримка цілком можлива через впровадження конкурсних механізмів, які можуть бути передбачені у місцевому нормативному акті, ухваленому відповідною місцевою радою.

Визначено, що характеристики партнерської взаємодії формуються та реалізуються лише в умовах, коли грамотно й відповідально реалізуються основні синергетичні принципи. Наприклад, реалізація правового принципу та принципу законності в партнерських відносинах забезпечує визнання законності основних життевих інтересів кожного суб'єкта партнерства всіма сторонами, що є базовою основою їх взаємодії, встановлення певних норм відповідальності за розробку, прийняття й виконання укладених договорів та угод. У цьому зв'язку найважливіші принципи партнерства - взаємодопомога, вимогливість, взаємоповага, чесність і висока відповідальність кожного партнера - набувають особливого значення.

В умовах соціально-економічної нестабільності та кризових явищ найбільш актуальним вважається здійснення інфраструктурних проектів, де кожна із сторін робить свій внесок у загальний проект. Так, з боку бізнесу таким внеском є: фінансові ресурси, професійний досвід, ефективне управління, гнучкість та оперативність у прийнятті рішень, здатність до інновацій тощо. Обгрунтовано, що серед пріоритетних напрямів розвитку партнерства між бізнесом та органами місцевого самоврядування на рівні міста, які поки що в Україні не отримали належного розвитку: соціальна, транспортна і виробнича інфраструктура, зокрема, житлово-комунальне господарство, будівництво і експлуатація доріг, електричних мереж, портів, трубопроводів; охорона здоров'я і соціальні послуги; інформаційно-комунікаційна підтримка підприємницької діяльності. Слід зазначити, що в зарубіжних країнах партнерство між бізнесом та органами місцевого самоврядування стало своєрідною альтернативою приватизації важливих галузей чи об'єктів (електроенергетики, транспорту, комунального господарства тощо). Не маючи фінансової можливості забезпечити розширений розвиток у цих галузях, органи місцевого самоврядування передають їх у довгострокову оренду (концесію) бізнесу, залишаючи за собою право контролю за їх діяльністю.

У результаті аналізу в історичній ретроспективі зарубіжного досвіду сфеpi партнерства визначено, що різні види партнерства сьогодні є складовою моделі надання послуг, яка поширена у більшості держав 3 ринковою економікою на рівні розвитку міст. Реалізація проекту на рівні міста у межах партнерства вимагає вирішення величезної кількості організаційних, юридичних, методичних та інших проблем. Перша проблема: недосконалість законодавчої системи реалізації проектів різних видів партнерства. Неузгодженість таких питань, як розміри та форми участі кожної сторони партнерства, типи i умови угод 3 приватними партнерами, розподіл ризиків і відповідальності і т. д., уповільнює процес розробки і реалізації проектів партнерства на рівні міста. Друга проблема: невисокий рівень компетентності посадових осіб місцевого самоврядування у сфері партнерства. Низький рівень компетентності працівників муніципальних органів влади в галузі партнерства стає серйозною перешкодою для успішної 
розробки і реалізації партнерства місцевої влади, бізнесу та недержавних організацій. Для вирішення цієї проблеми необхідно, по-перше, сприяти розвитку програм підвищення кваліфікації службовців органів місцевого самоврядування в сфері партнерства шляхом введення в програми курсів підвищення кваліфікації цих службовців необхідних дисциплін; по-друге, сприяти включенню в навчальні плани вищих навчальних закладів дисциплін у галузі різних видів партнерств; по-третє, створити на сайтах спеціалізованих структур з розвитку партнерства розділ, де розміщуватиметься інформація про партнерство у сфері управління містом, затверджені типові галузеві угоди щодо проектів партнерства з урахуванням галузевої специфіки, де муніципальні службовці, а також фахівці приватного сектора зможуть отримати цікаву для них інформацію з даних питань.

Третя проблема: недостатність пропозицій проектів, що реалізовуються на засадах партнерства. Для вирішення проблеми дефіциту пропозицій важливо розширити пріоритетні галузі реалізації проектів партнерства на рівні міст. Зазвичай, механізм партнерства застосовується в таких сферах, як транспортна (автодороги, залізничні колії, аеропорти, порти, трубопровідний транспорт) i соціальна інфраструктура (охорона здоров'я, освіта, розваги, туризм), ЖКГ (водопостачання, електропостачання, очищення води, газопостачання і ін.), в інших сыерах (в'язниці, оборона, об'єкти військової сфери). На окрему увагу заслуговує проблема недостатньої інформованості комерційних структур про можливі моделі партнерських відносин і способи їх оптимізації [4].

Четверта проблема: високий рівень ризиків і складності залучення приватними партнерами великих фінансових коштів на умовах, що дозволяють успішно фінансувати довгострокові проекти розвитку інфраструктури.

П’ята проблема: відсутність спеціалізованих організаційних структур управління партнерством на рівні міст. У даний час у містах України управлінням партнерством пробують займатися в основному різні структурні підрозділи виконавчих органів міських рад, дії яких часто не скоординовані, що $\epsilon$ причиною відсутності комплексної політики у сфері партнерства в місті. Істотна організаційна розосередженість свідчить про недосконалість управління у сфері партнерства на рівні міста.

Така функція має бути передана єдиній організаційній структурі. Це дозволить: сконцентрувати й ефективніше використовувати наявну інформацію про проекти партнерства; приватним інвесторам краще працювати з однією організацією, ніж з багатьма.

Основні компетенції такої структури можуть включати: вивчення політики 3 питань партнерства та надання необхідних рекомендацій щодо написання проекту партнерства; підготовку пропозицій з боку органів місцевого самоврядування стосовно проекту партнерства; координація діяльності 3 іншими публічними органами, що в межах своєї компетенції регулюють діяльність приватного партнера; інформаційне забезпечення та підтримка органів місцевого самоврядування та їх партнерів; здійснення техніко-економічної оцінки доцільності реалізації проектів державно-приватного партнерства; підготовка рішення щодо реалізації проекту в межах державно-приватного партнерства.

На сьогодні слід констатувати, що співробітникам та керівникам органів місцевого самоврядування на рівні міста необхідна низка нових компетентностей, знань, навичок та вмінь, розвиток яких підвищуе ефективність реалізації державно-приватного партнерства на рівні міста. Серед них слід відзначити вміння та навички ведення переговорів, укладання контрактів та ведення фінансових справ організації.

Одним із ключових завдань є перехід від традиційних підходів, які засновані на «витратному» принципі, до формування таких умінь, які спрямовані на підвищення результативної діяльності 3 партнерства. Зазначене включає в себе необхідність урахування специфіки та цілей партнерства, досягнення яких прагне приватний партнер щодо виконання фінансових зобов'язань, моніторингу ефективності діяльності інших партнерів, а також прогнозування можливих ризиків, здатних підірвати успіх щодо реалізації проекту. Більше того, посадові особи місцевого самоврядування також потребують розуміння функціонування тих секторів економіки, в яких їм потрібні партнери.

Посадові особи місцевого самовряду- 
вання, як правило, не завжди володіють вищевказаними вміннями та навичками. У цьому зв'язку одним із способів забезпечити структури органів місцевого самоврядування на рівні міста необхідними сучасними навичками та вмінням у сфері публічно-приватного партнерства є залучення спеціалістів з приватного сектора, які володіють відповідним умінням та досвідом у вищевказаній сфері.

Висновки. Узагальнення наукових теорій у контексті взаємодії органів місцевого самоврядування, бізнесу, громадських організацій дає підставу розуміти під «партнерством на рівні міста» систему відносин між органами місцевого самоврядування та іншими партнерами, при реалізації яких ресурси взаємодіючих сторін поєднуються 3 розподілом відповідальності, винагород та ризиків між ними, для взаємовигідного співробітництва на довгостроковій основі довіри для створення нових або модерніза- ції (реконструкції) діючих об'єктів, які потребують залучення інвестицій та надання послуг.

Основними проблемами на шляху запровадження механізмів партнерства на рівні міста виступають: недосконалість законодавчого забезпечення реалізації різних видів партнерства; дефіцит підготовлених фахівців з проблем партнерства; недосконалість інституційної та організаційної складової партнерств на рівні міста.

Констатовано, що необхідність формування інституту партнерства на рівні міста об'єктивно обумовлена чинниками як внутрішнього, так і зовнішнього характеру. В сучасних економічних і політичних умовах розвитку країни саме партнерство між органами місцевого самоврядування, бізнесом та недержавними організаціями зможе стати реальним інструментом подолання кризових явищ і прискорення темпів соціально-економічного розвитку міст.

\section{СПИСОК АIТЕРАТУРИ:}

1. Про місцеве самоврядування в Україні. Закон України від 21.05.1997 р. // Відомості Верховної Ради України - 1997. - № 24, ст. 170.

2. Запатрина И.В. Роль государственно-частного партнерства в модернизации развивающихся экономик // Экон. наука соврем. России. - 2012. - № 1. - С.49-61.

3. Государственно-частное партнерство в Украине - Arzinger. - 2 издание. -Киев, 2010. $173 \mathrm{C}$.

4. Михеев О.Л. Частно-государственное партнерство: формирование общей среды развития // Страховое дело. - 2011. - № 7. - С.14-20.

\section{REFERENCES:}

1. Pro mistseve samovryaduvannya $\mathrm{v}$ Ukrayini. Zakon Ukrayiny vid 21.05.1997 r. (About mistseve samovryaduvannya in Ukraïni. The Law of Ukraine od 21.05.1997) //Vidomosti Verkhovnoyi Rady Ukrayiny - 1997. - № 24, p. 170.

2. Zapatrina I.V. Rol gosudarstvenno-chastnogo partnerstva v modernizatsii razvivayuschihsya ekonomik (The role of public-private partnerships in the modernization of the emerging economies) // Ekon. nauka sovrem. Rossii. - 2012. - № 1. - P.49-61.

3. Gosudarstvenno-chastnoe partnerstvo v Ukraine (Public-private partnership in Ukraine) Arzinger. - 2 izdanie. -Kiev, 2010. - 173 p.

4. Miheev O.L. Chastno-gosudarstvennoe partnerstvo: formirovanie obschey sredyi razvitiya (Public-private partnership: the formation of a common development environment) // Strahovoe delo. - 2011. - № 7. - P.14-20.

Запорожець Сергій Андрійович - аспірант

Одеський регіональний інститут державного управління Національної академії державного управління при Президентові України

Адреса: 65009, м. Одеса, вул. Генуезька, 22

E-mail:sergzap@yandex.ru

Zaporozhec Serhiy Andriyovych - postgraduate

Odesa regional institute of public administration National academy of public administration, office of the President of Ukraine

Address: 22, Henuez'ka Str., Odessa, 65009.

E-mail:sergzap@yandex.ru 